\title{
Pilot experience of Service-Learning with Universitary Students: Learning about inclusive education with a Multiple Intelligences Project and Interactive Groups
}

DOI: $10.46932 / \mathrm{sfjdv2n1-043}$

Received in: November 1st, 2020

Accepted in: December 30th, 2020

\section{María Dolores Pérez Bravo}

Assosiate professor. Evolutive Psichology and Education Department. Faculty of Education of Universidad Autónoma of Madrid.

María Ferrezuelo Caro

Primary school degree student. Faculty of Education of Universidad Autónoma of Madrid

Emilio Severo Sánchez Jiménez

Teacher and training coordinator of Primary School in El Casar - Guadalajara (Spain)

\author{
Alberto Bermejo Santibáñez \\ Teacher of Primary School in El Casar - Guadalajara (Spain)
}

\begin{abstract}
Service-Learning is an experience highly recommended for university students, and also an excellent opportunity to come into contact with their future careers. Students from Faculty of Education of Universidad Autonoma of Madrid, participated in a pilot experience collaborating with the development of an educative project in a Primary Public School in the municipality of El Casar (Guadalajara-Spain). The project consisted about designing eight activities for each Multiple Intelligences of Gardner's Theory and implementing them through an Interactive Groups methodology. There was an adult tasked with explaining and moderate each group. After a previous theoretical training, the university students collaborated in the production of materials and activities, and the implementation of the workshops in the school, participating in the assessment afterwards. All the university students achieved knowledge related to methodology used in the project, inclusive education and also they have the opportunity to live how a Primary Public School works. They themselves give a punctuation of 9.57 out of 10 to the experience.
\end{abstract}

Keywords: Learning, service, multiple intelligences

\section{INTRODUCTION}

The Service-Learning is a learning technique or innovative methodology which joins, integrates and combines learning, teaching and reflection together with social compromise and community service. "It is a pedagogical methodology that encourages students learning through their active participation in experiences associated with community service" (Folgueiras, Luna and Puig, 2013). As Kolenko, Porter, Wheatley and Colby (1996, quoted in Folgueiras, Luna and Puig, 2013) point out, one of the values and principles in which Service-Learning practice success is based on is the reciprocity, because it is fundamental that the relationship has to be a mutual learning experience. University and higher education is one of the fields where Service-Learning appears as a methodological strategy efficient in order to train 
students to enter into the labor market and contribute to their development as citizens. "The practical consequences carry out in the university sphere, support the Service-Learning as a powerful didactic strategy and also it can be structured in multiple ways, in projects in a universitary level, faculties and specific subjects" (Rodriguez, 2014). In the same manner, it is a very profitable pedagogic resource in the initial teacher training and undergraduate students. "Service-Learning is a powerful tool that contributes to the professional teacher's competency development and improves the compromise of the students with community and social justice" (Aramburuzabala and García, 2012). García and Sánchez (2017) set out that one of the university areas in which Service-Learning is achieving a further expanse is in the initial teacher training, where its role in development of inclusive education, in the articulation of the social justice, in educative accompanying or as a teacher innovation proposal are resulting crucial. Even more,

"Students learn to be reflexive professionals, sensitive towards matters based on the community, through Service-Learning experiences, teaching school. They learn to reflect on their own thoughts, learning and practices critically while they are working with children in specific contexts" (pp.30)

Therefore, the Service-Learning experience that we submit in this text has been a pilot experience carried out during the initial teaching training, in which 7 students of the subject of "Psichopedagogical basis for educative inclusion" have participated, being the lecturer of them one of the author of this text, and in collaboration with the subject of "Learning and development II", for the academic year 2017/2018. Both subjects belong to the first year of primary school teaching degree in the Faculty of Education of Universidad Autónoma (Madrid).

The aforementioned experience was developed in the school "María Montessori", one of the three public schools of the municipality of El Casar in Guadalajara (Spain), and in which university students had the opportunity to collaborate in an innovative educative project that had been carrying out that academic year, called "Working multiple intelligences with interactive groups". This project came up in the school because of the need to foster an educative transformation, by means of the realization of innovative practices that boost a more inclusive education.

\section{GENERAL DESCRIPTION}

The educational innovation project that was being performed at the school "María Montesori" fits perfectly with the theoretical knowledge that students had to learn in both subjects and they were able to learn in a practical and experiential way, at the same time they provided a service to the educational community of the school. In fact, on the study guide of the subject of "Psichopedagogical basis for educative inclusion" it could be found as contents block one called "Strategies and adaptation measures to the individual differences in the inclusive school. Orchestrating the presence, the learning and the 
participation of all the students", inside which, there is a specific lesson with it is expected that students achieve the resources and strategies needed for an inclusive education, the importance of the collaborative work among the teacher team, the educative and psychopedagogical orientation services, the families and the students, and the concept of Learning communities. Moreover, in the student guide of the subject "Learning and development II", one of the lessons that appears is "Intelligence and scholar learning. Learning styles and the role of the teacher", in which Gardner's Multiple Intelligences theory is addressed (1987). In addition, as the school expressed the need of being open to families and the surrounding institutions, pursuing boosting participation and collaboration of educational community in order to get the educative project of the ground, it was set up this Service-Learning pilot experience at the school, with the participation of university students as part of the educational community. So that, the main purpose of starting up this pilot experience was analyzing its possible result in order to establish a Service-Learning for the next school years for these subjects and continuing the collaboration with the innovative educative project of the school.

In conclusion, this experience provided the school an exceptional opportunity for the university students to know first-hand how educational public system works, becoming this knowledge as one of the needed contents to form citizens (Peces-Barba 2007, quoted in Puig, Gijón, Martín y Rubio, 2011), at the same time that they were able to form a personal and sensible opinion about the general working of the school and the specific project carried out. They were able to observe the educational community needs, giving contributions and establishing ties between the participants of the projects, being part of the proper community.

\section{PARTICIPANTS}

As explained above, the participants in this Service-Learning experience were seven students, namely four girls and three boys, all of them studying the first year of Primary Education teaching degree and attending the subjects of "Psichopedagogical basis for educative inclusion" and "Learning and development II", in the Faculty of Education of the "Universidad Autónoma" (Madrid). They were aged between 18 and 26 years old, with an average of 20.12. All of them expressed their interest in carrying out the Service-Learning and their commitment to take part in the educational educative project

\section{DETECTED NEEDS}

The innovative project of the school appeared because of the need of changing the educative methodology, what is in many cases traditional. It was expected to improve diversity outreach present in the school, arising at this point a social necessity, and being open to the educational community involving 
them in the school life with the objective of getting the educative project off the ground. It was intended to improve both the social image and the relationship with the school and its surroundings.

For this reason, in order to start up the Multiple Intelligences workshops, they were needed more human resources than those ones were at school. At the beginning, students' families were taken into account, although after some sessions and in the training term, it was noticed that the mothers (just a mother came) were not enough neither for carrying out the required work of the project, nor for covering the "learning steps" in vary grades. There was running the risk of not being able to carry out the project, and because of that, giving up the social and educational changing. To avoid that, it was required the participation of other members of the educational community, and they were the university students.

\section{SERVICE PERFORMED}

The participation of the seven students in order to cover the human resources needed and take part in the preparation as the practice development of the Multiple Intelligences workshops was essential. These workshops consisted in working the eight Gardner's Multiple Intelligences (1987) with students from different primary school grades. For that, they were designed eight activities related to a common learning content and they were carried out with the schoolchildren in interactive groups and an adult who explained them and boosted the peer assistance during the task. In such a way that the schoolchildren of different grades were doing these activities as learning corners or steps, taking part simultaneously in the classroom or in different places in the school (corridors, staff room, music classroom, etc.). In fact, each team took turns over the different steps completing all of them and the "Multiple Intelligences palette". The university students participated in the preparation of "Multiple Intelligences palette" providing with ideas for the activities of the workshops and making didactic material. They collaborated together with the school families, in the development and performance of the activities at the classroom, taking part of the interactive groups as person responsible or in charge with teaching the Multiple Intelligences workshops with schoolchildren. The different "Multiple Intelligences palettes" designed for any primary grade were implemented at the school on different days and these university students were very helpful for the achievement of the academic and organizational objectives of the project. Furthermore, they participated in the assessment of the teaching and learning process, providing proposals for improving, establishing ties and boosting the relationships with the other participants in the project as the schoolchildren. The effect of the university taking part of the project benefited a greater spreading of the innovative performs and the participation of the educational community in the school so as to achieve a social change and a greater attention to the diversity outreach. Once the experience finished, the school 
center gave a certificate to all the university students who had performed the service, in order to recognize their work in the project.

\section{LERNINGS ACHIEVED}

The eight university students got a theoretical training previously related to the innovative educational project in which they were about to take part, introducing them to its theoretical basis, its objectives and its implementation phases. As a consequence, the students involved in this experience, learned different theoretical contents about the fundamentals of Inclusive Education and about new teaching and learning methodologies related to both degree subjects, offering their service to the educational community of the school center. These theoretical contents were specifically the Gardner's Multiple Intelligence Theory (1987) and its practical application in the classroom through the use of "Multiple Intelligences palettes", as well as the knowledge of the interactive groups as a didactic strategy in favor of diversity outreach. Through an experiential-based learning, they were able to learn practice knowledge according with the theoretical contents aforementioned, and they were aware of the benefits and advantages of working in the classroom with these kinds of active methodologies.

In fact, the Gardner's Multiple Intelligences Theory has positive effects in diversity outreach; it encourages the inclusion of all the schoolchildren in the class, through considering each student has diverse capacities, abilities and potentialities that make him/her unique; it defines that educational environment should focus on working and helping the development of the eight intelligences, valuing each student according to his/her differences and taking profit from this diversity for the personal enrichment (Nadal, 2015). The interactive groups, the educative participation in the community and the training of families are part of the set of Successful Educational Actions which have been identified by the INCLUDE-ED Integrated Project (2006-2011) as those practices that produce both equity and effectiveness at the same time, which contribute to learning optimization and academic results of all the students in diverse contexts and countries and improve the coexistence in the educative center (Valls, Prados and Aguilera, 2014).

It is worth mentioning that in order to assess the knowledge achieved, the students had to develop a critical and reflexive work in groups about the theoretical contents and their personal experience in the innovational educative project. This writing was presented to the rest of their classmates of the "Learning and development II" subject, and got a mark by their lecturer.

As regards the learning results and the competencies achieved, they appear in the student guides of the subject of the academic year 2017/2018, considering them as the competences that have been 
strengthened in the university students after having carried out the Service-Learning experience. As an example, some of the learning results occurred as it is displayed on the guide.

- Applying and promoting the improvement of educational practices

- Using theoretical and methodological knowledge from different learning theories in analysis, design and assessment of social and educational programs assigned to primary students

- Designing, planning and assessing activities which promote the learning in class

- Designing and applying interventional programs which boost the inclusion of students with special needs in their immediate environment

- Designing programs for families with children who have special needs

- Producing research reports

- Displaying the research work that has been made orally

Regarding the competencies achieved for the subject of "Psichopedagogical basis for educative inclusion", according with the student guide, they are:

- Identifying and planning the resolution of educational situations that affect the schoolchildren with different abilities, learning pace and other personal or social conditions.

- Facilitating the achievement of strategies to initiate research and problem solving processes related to the attention of the students with specific educational needs

- Analyzing the complexity of curriculum and design curricular adaptations, through specific interventional programs, that meet the diversity of educational needs presented in the students in their different learning and teaching context

- Designing, planning and assessing learning and teaching processes, so individually as in collaboration with other teachers and workers in the school

- Designing and regularizing learning space in diversity contexts that take into account gender equality, equity and human rights respect that conform with values of citizen development

- Contributing to strengthen respect values, tolerance, responsibility and professional ethic toward the differences, as well as promoting the reflexive thinking and relational competencies which support interprofessional collaboration

- Participating responsibly in both formal and informal situations which become personal compromises and encourage social inclusion

- Being aware of the necessity of pedagogical individualization in order to attend responsibly to diversity outreach in the scholar context

And the compentences achieved for the subject of "Learning and development II" are the following: 
- Acknowledgment of diversity and multiculturalism

- Teamwork

- Getting the students to know how to apply their knowledge in their work or vocation in a professional manner and they possess the competencies just shown through arguments and problem solving inside their field of study

- Getting the students to be able to transmit information, ideas, problems and solutions to a an audience so specialize as non-specialize

- Designing, planning and assessing teaching and learning processes, so individually as in collaboration with other teachers and professionals of the educative center

- Encouraging harmony inside and outside the classroom, solving behavior problems and contributing to a pacific solution of conflicts. Boosting and valuing the sacrifice, constancy and personal discipline of the students

\section{CONCLUSION}

As regards the results of the experience, so that all the involved agents in the project were able to convey their sensations at its the end, a survey had been provided to teachers, families and university students. According to the answers, the university students were very pleased with the experience, assessing it positively. Just like in other texts as Folgueiras, Luna and Puig (2013) and as Aramburuzabalay García (2012), a high rate of satisfaction could be observed among the participant students in Learning-Service. In fact, the data analyzed by Folgueiras, Luna and Puig (2013) indicated that the students felt especially satisfied because of having achieved some leanings based on their collaboration with social and educative organizations, as well as the opportunity to integrate theory and practice. The results of the enquiry of Aramburuzabala and García (2012) shown the students had an positive opinion about using Service-Learning in the subject, to the point of $78.1 \%$ of them opined that it should be integrated in a larger range of subjects of the teaching degree, and $83.8 \%$ of them manifested that they would like to participate in other Learning-Service experiences throughout their degrees.

In our case, most of the students conveyed that the experience had been enriching and all of them would like to do it again. In fact, the mean score with which the experience was rated by them was 9.57 out of 10 .

Particularly, some of the answers that the students manifested to the question about how they would describe their experience they also mentioned the utility of it to learn multiple intelligences knowledge. 
According to the results got from this pilot experience, it is expected to configure a formal collaboration, stabler, so as the university students of the aforementioned subjects are able to perform Learnig-Service experiences in different projects which will be carried out in the scholar center and which are connected to their theoretical content. Although, with regard to next scholar years, some points of the Learning-Service experience would be needed to be improved, so that related to the planning and designing, as in its programmation, implementation and assessment. As an example, regarding the evaluative improvements, throughout the four-month period some meetings or spaces in order to share debate and critical reflection might take place which allow to carry out an analysis of the service and the learning achieved, connecting it even more consciously with the subject. And, as regards the organizational improvements, a further planning and a programming more defined in each training action, with a proper flexibility and timetable anticipation, would be suitable.

In conclusion, we would like to give emphasis to the point of, as it is mentioned in previous research, the Learning-Service is an educative methodology which exerts a great pedagogical work because it connects theory and practice and joins theoretical learning with the community service. Therefore, these experiences should be highly recommendable among the university students. 


\section{REFERENCES}

Aramburuzabala, P. y García, R. (2012). El Aprendizaje-Servicio en la formación de maestros. CIDIU, Revista del Congrés International de Docència Universitaria i Innovació, 1, 1133.

Folgueiras, P., Luna, E. y Puig, G. (2013). Aprendizaje y Servicio. Un estudio del grado de satisfacción de usuarios en estudiantes universitarios. Revista de Educación, 362, 159-185.

García, M y Sánchez, L. (2017). Aprendizaje y Servicio y el desarrollo de las competencias emocionales en la formación inicial del profesorado. Contextos educativos, 20, 127-145.

Gardner, H. (1987). Estructuras de la mente. La Teoría de las Múltiples Inteligencias. Ciudad de México: Ed. Fondo de Cultura Económica.

Nadal, B. (2015). Las Inteligencias Múltiples como una estrategia didáctica para atender a la diversidad y aprovechar el potencial de todos los alumnos. Revista Nacional e Internacional de Educación Inclusiva, 8

Rodríguez, M (2014). El Aprendizaje-Servicio como estrategia metodológica en la Universidad. $\begin{array}{llll}\text { Revista Complutense } & \text { de } & \text { Educación, } & \text { 25(1), }\end{array}$

Rovira, J.M., Gijón, M., Martín, X. y Rubio, L. (2011). Aprendizaje-servicio y Educación para la Ciudadanía. Revista de Educación, $\mathrm{n}^{\circ}$ extraordinario 2011, 45-67

Valls, R., Prados, M. y Aguilera, A. (2014). El proyecto INCLUD-ED: Estrategias para la inclusión y la cohesión social en Europa desde la educación. Investigación en la Escuela, 82, 31-43. 